\title{
SACRO-ILIAC JOINT IN ADULT RHEUMATOID ARTHRITIS AND PSORIATIC ARTHROPATHY*
}

\author{
BY \\ A. ST. J. DIXON AND E. LIENCE \\ Postgraduate Medical School, Hammersmith Hospital, London
}

Sacro-iliitis is held to be an early and constant sign of ankylosing spondylitis (AS), a frequent sign of Reiter's disease, and one by which it is possible to distinguish these diseases radiologically from rheumatoid arthritis (RA).

Recently Cohen, McNeil, Sharp, Schubart, Calabro, and Calkins (1959), in a combined clinical and radiological study of AS and RA, briefly noted that "the sacro-iliac joints were involved in fifteen (27 per cent.) of 55 patients judged clinically to have only peripheral joint disease", a finding which might impair the validity of sacro-iliitis as a differentiating sign and might suggest that the two diseases, RA and AS, were part of the same pathological process.

The radiographic appearance of the normal sacro-iliac joint varies from individual to individual, and with age, sex, radiological technique, and the density of soft tissue shadows. These variable factors open the possibility of error in diagnosis. We felt that the only satisfactory method of determining the true incidence of radiological sacroiliitis in RA would be that of the controlled study.

\footnotetext{
* Read at a meeting of the Heberden Society on December 3, 1960.
}

\section{Material}

297 radiographs of the sacro-iliac joints (Table I). These were selected as follows:

56 films were from adult patients with "classical" rheumatoid arthritis (Ropes, Bennett, Cobb, Jacox, and Jessar, 1959), in whom a modification of the differential agglutination test (D.A.T.) (Scott, 1952) was positive. These patients had all been under the care of Prof. E. G. L. Bywaters or one of us (A.S.D.), and the great majority had been personally studied as in-patients.

56 control films from patients matched for age and sex were taken from the files of the Radiology Department of patients with miscellaneous nonrheumatic conditions.

40 films from similarly studied adult patients with "definite" and "probable" rheumatoid arthritis (American Rheumatism Association Criteria), but with a negative D.A.T., with $\mathbf{4 0}$ matched control films.

33 films from patients with psoriasis and chronic inflammatory polyarthritis, with 33 matched control films. The patients in this group have been separately described (Lience, 1960).

36 films from patients with ankylosing spondylitis, found by reference to our files. These patients were either seen personally or were amongst

TABLE I

AGE AND SEX OF PATIENTS STUDIED

\begin{tabular}{|c|c|c|c|c|c|c|c|c|}
\hline \multirow{2}{*}{ Films Studied } & \multicolumn{3}{|c|}{ No. of Patients } & \multicolumn{2}{|c|}{ Mean Age (yrs } & \multicolumn{2}{|c|}{ Age Range (yrs) } & \multirow{2}{*}{ Comment } \\
\hline & Total & Male & Female & Male & Female & Male & Female & \\
\hline "Classical" Rheumatoid Arthritis & 56 & 23 & 33 & 54 & 52 & $22-73$ & $20-73$ & $\begin{array}{l}\text { American Rheumatism Association } \\
\text { Criteria: "Classical" }\end{array}$ \\
\hline 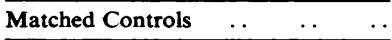 & 56 & 23 & 33 & 54 & 52 & $22-72$ & $20-70$ & \\
\hline Sero-Negative Rheumatoid Arthritis & 40 & 13 & 27 & 45 & 59 & $25-75$ & $20-70$ & $\begin{array}{c}\text { American Rheumatism Association } \\
\text { Criteria: "Definite" } \\
\text { "Probable" }\end{array}$ \\
\hline Matched Controls & 40 & 13 & 27 & 43 & 60 & $25-75$ & $22-70$ & \\
\hline Psoriasis and Arthritis & 33 & 13 & 20 & 46 & 52 & $29-62$ & 13-75 & \\
\hline Matched Controls $\quad .$. & 33 & 13 & 20 & 46 & 52 & $29-62$ & $13-77$ & $\begin{array}{c}\text { Controls without psoriasis and } \\
\text { without arthritis }\end{array}$ \\
\hline Ankylosing Spondylitis & 36 & 31 & 5 & 43 & 40 & $21-73$ & $33-47$ & Positive controls \\
\hline
\end{tabular}


those previously reviewed from this centre (Wilkinson and Bywaters, 1958).

Antero-posterior radiographs of the pelvis or lumbar spine are taken routinely on in-patients, but only when clinically indicated on out-patients-for example, by possible hip pain. Thus the study is weighted in favour of arthritis with more severe disease and hip involvement. A film was selected from the file of each patient or control according to the following order of preference:

(1) antero-posterior projection of whole pelvis;

(2) antero-posterior projection of both sacro-iliac joints;

(3) antero-posterior projection of lower lumbar spine, including sacro-iliac joints;

(4) antero-posterior projection of pelvis, as in views of the bladder before excretion urography.

Each type of projection was represented in each disease or control group, but there were slightly more projections of types (3) and (4) amongst the controls. We did not find that this interfered with reading the films when in random order.

Two films, one in the D.A.T.-positive and one in the D.A.T.-negative R.A. series, were rejected because Paget's disease of the pelvis made reading of the sacroiliac joints unreliable. Their paired control films were similarly rejected.

\section{Reading of Films}

Each film was masked to exclude identifying marks and hips so as to reveal a rectangle containing both the sacro-iliac joints and the space between. The films were then shuffled, numbered, and arranged in random order, and read by both authors, jointly, and at a single sitting. The whole procedure was repeated at second and third readings. The first reading was regarded as a "practice run", and the results of the second and third readings were used for evaluation of repeatability and diagnosis.

Each sacro-iliac joint was thus read three times for each of the following characteristics: erosions, sclerosis, narrowing, and widening. Each characteristic was graded 0-3 (indicating no change, doubtful, definite, or severe change respectively). Grade 3 narrowing indicated fusion of the joint. When one part of a joint seemed wide and another narrow the overall impression was recorded. Fused joints cannot be graded for erosions and sclerosis, and films showing fusion of either joint were excluded from further analysis. Porosis of the bones forming the joint is another sign of sacro-iliitis, but one which we were unable to judge reliably because of the variation in density of the films. Attention was mainly directed to the synovial joint, which occupies the lower one-half to twothirds of the apparent joint space according to the view. (The upper part of the joint is a synostosis.)
Help was also obtained by reference to the disarticulated skeleton and to the anatomical and

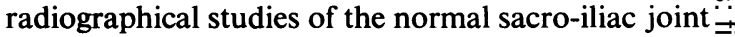
of Forestier, Rotés-Querol, and Jacqueline (1950). Observations were also made on the ligamentouso ossification where this was visible within the rectangle revealed by the masking.

\section{Results}

Repeatability (Table II).-Grading could be $\vec{\circ}$

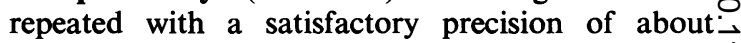
84 per cent. and changes of two or three grades on $\vec{\omega}$ repetition were not seen with erosions or sclerosis? and were rare for widening or narrowing. Of more clinical significance is the repeatability of the diag-i nosis of definite abnormality. In the second $\dot{\omega}$ column are listed the percentage scored for Grade 1 is or 0 on both readings (i.e. pathology absent or doubtful). This corresponds to the normal cutting을 line of clinical diagnosis and at this level only 4 per cent. or less of all films have been allotted on $\mathbb{\Phi}$ one occasion to a normal or probably normalo category and on another occasion to an abnormal $\frac{\mathbb{}}{3}$ category.

TABLE II

REPEATABILITY OF GRADING (per cent.)

\begin{tabular}{l|c|c|c}
\hline \multicolumn{1}{|c|}{ Criterion } & $\begin{array}{c}\text { No Variation in } \\
\text { Grade between } \\
\text { 2nd and 3rd readings }\end{array}$ & $\begin{array}{c}\text { No Change across } \\
\text { Line between Grades } \\
\text { and Grade 2 }\end{array}$ \\
\hline Narrowing & $\ldots$ & 84 & 96 \\
\hline Erosions & $\cdots$ & 85 & 98 \\
\hline Sclerosis & $\cdots$ & 86 & 96
\end{tabular}

These figures must also be related to the totalo diagnoses of abnormality as well as to the totalo number of films studied. Thus consistency was shown three times as often as inconsistency in the $\frac{0}{3}$ selection of definite erosions, and two and a half. times as often as inconsistency in the selection of definite narrowing, but as many films were read inconsistently as consistently for the presence of? Grade II or more sclerosis. Definite "widening"? of the joint was difficult to judge, since it was read․ inconsistently about twice as frequently as con- $\sim$ sistently and has therefore not been further analysed:

“Classical" RA (Table III).-Only 74 out of 112 W joints of patients with "classical" RA were con-0 sistently diagnosed as Grade 0 (i.e. no narrowing) compared with 106 out of 112 joints of controls. The difference is significant $(P=<0.01)$, and at $\stackrel{+}{+}$ each level of grading more RA films were thought to show narrowing. 
TABLE III

56 FILMS FROM PATIENTS WITH "CLASSICAL" RHEUMATOID ARTHRITIS AND 56 CONTROLS

SUbJects

All Films

Narrowing
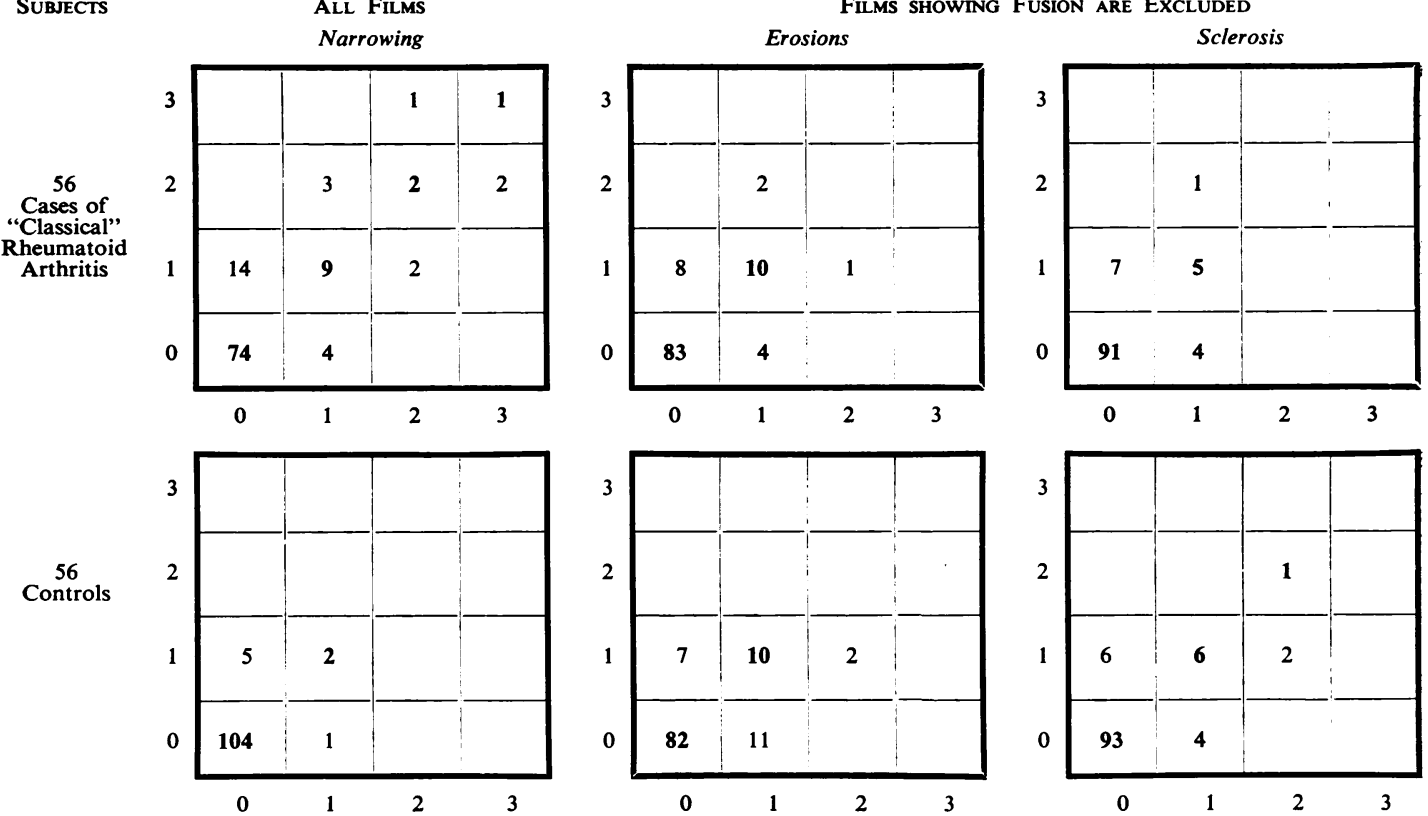

Note: In this and in Tables IV to VI, the numerals refer to the number of sacro-iliac joints. The grading for the second reading is given by the vertical scale, and for the third reading by the horizontal scale.

Thus consistent gradings will be found in heavy type in the central diagonal from bottom left to top right.

Two films graded as having a fused joint or joints at either reading have been omitted from the analysis of erosions and sclerosis, which shows that there is no difference in grading between the cases of classical rheumatoid arthritis and the controls for these features.

Radiological diagnosis is, in practice, a matter of assessing the total picture rather than of grading individual features. The great majority of the RA sacro-iliac joints could not be distinguished from those of the controls, but in one or two cases we did think it might be possible to recognize a "rheumatoid" sacro-iliac joint change, which occurs in older people and consists of narrowing, with small, ill-defined erosions and general osteoporosis without ligamentous ossification (as seen in the left sacro-iliac joint in Fig. 1 (overleaf), which was graded as showing doubtful erosions, sclerosis, and narrowing at both readings). The right sacro-iliac joint in the same subject had been graded as normal for all criteria at both readings.

To investigate this point further, the gradings of various criteria were related to the age of the patient (Fig. 2), which showed that narrowing of the sacroiliac joint was much commoner in D.A.T.-positive

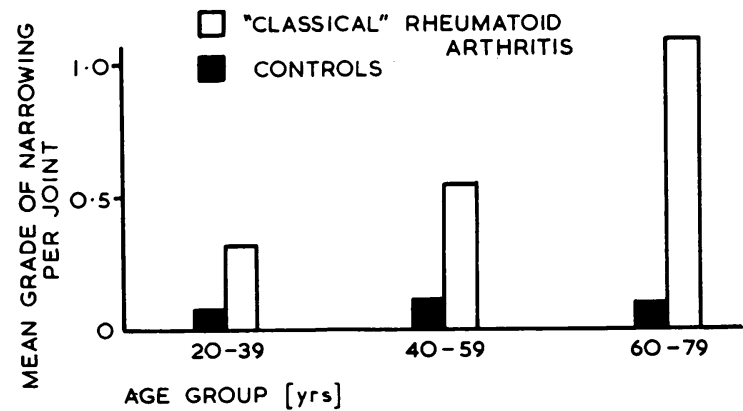

Fig. 2.-For each 20-year age group the total score for narrowing of both sacro-iliac joints has been summed up and divided by the number of films.

RA patients than in their controls at all ages. Moreover, the scores for narrowing increased with age and thus probably with duration of disease, whilst the scores for narrowing amongst the controls were scarcely affected by age. One man (Fig. 3, overleaf) and one woman with RA were thought to have fused sacro-iliac joints. Both had severe RA of at least 20 and 25 years' duration respectively, and both also had very severe involvement (without 


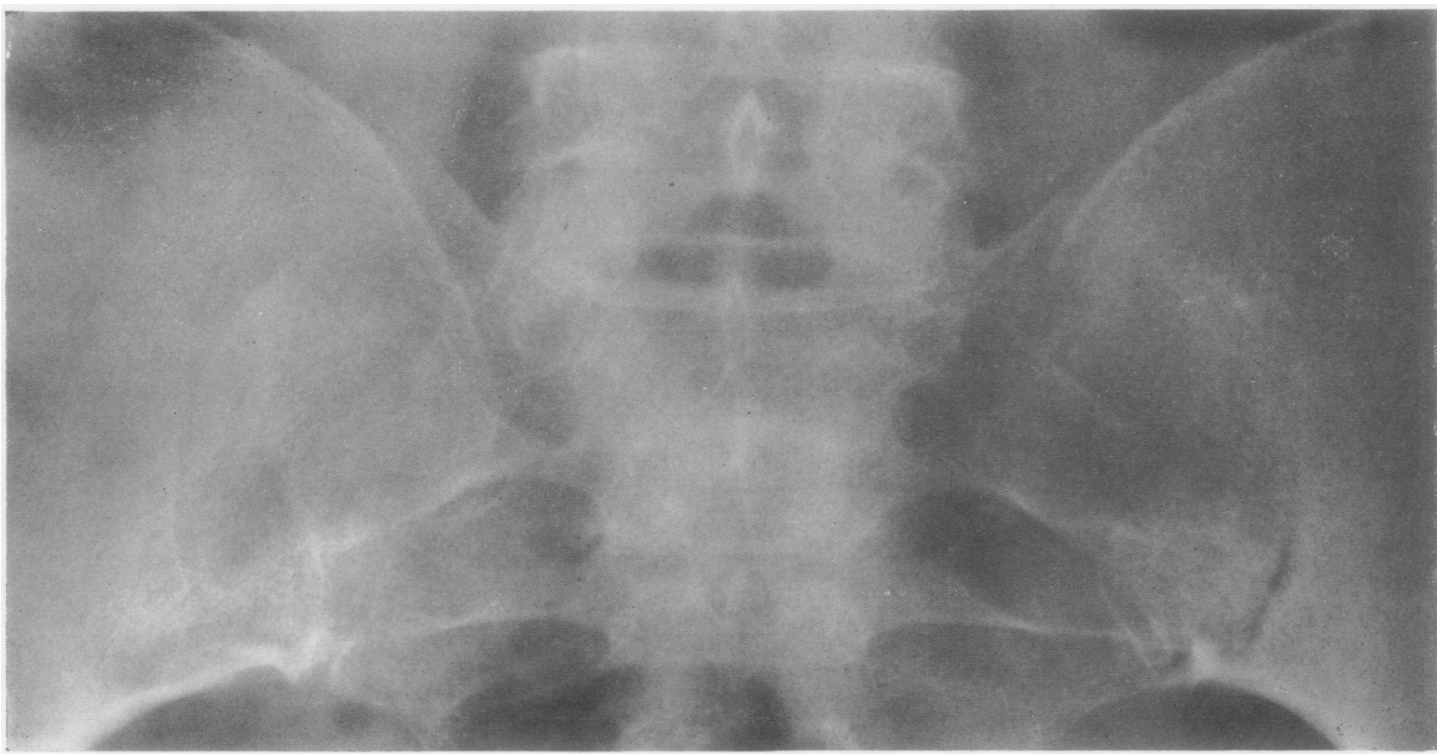

Fig. 1.-Grade 1 erosions, sclerosis, and narrowing in the left sacro- iliac joint of a patient with "classical" rheumatoid arthritis.

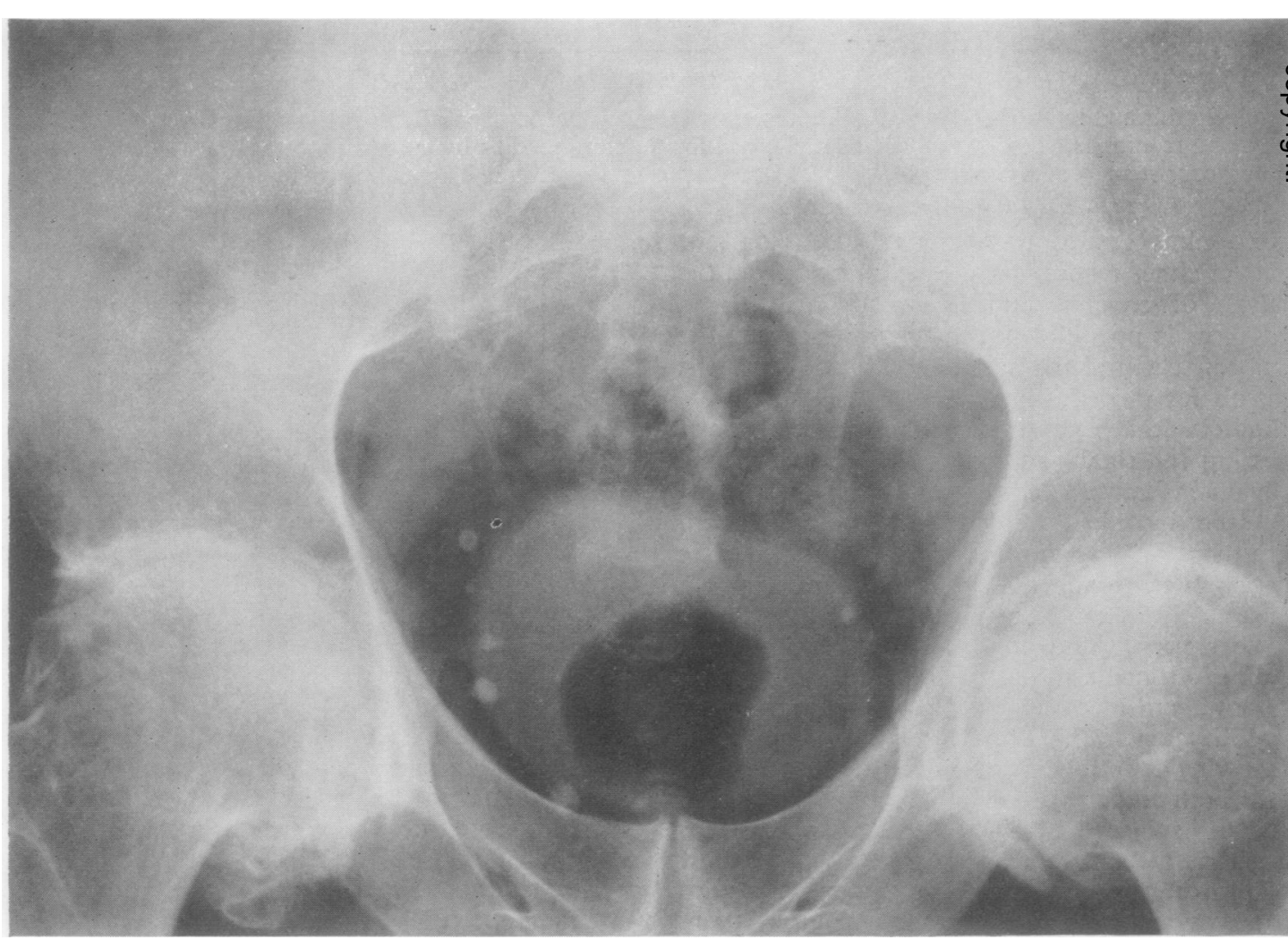

Fig. 3.-Fusion of sacro-iliac joints without ligamentous ossification in a man aged 64 with "classical" rheumatoid arthritis of 20 years' $\succeq$ duration and severe hip involvement. 
ankylosis) of the hips. Four patients with definite (Grade 2) narrowing also had some degree of clinical involvement of the hips. However, as there were also numerous patients with hip involvement, but without sacro-iliac narrowing, the association of hip involvement and sacro-iliac narrowing or fusion did not appear to be significant.

DAT-Negative RA.-Minor degrees of narrowing (Table IV) were diagnosed a little more frequently in the DAT-negative RA patients than in the controls, but the difference is not significant. A woman aged 73, a control, with Grade 3 narrowing (i.e. fused joints) at both readings (Fig. 4, overleaf), had no clinical or radiological evidence of spondylitis, but had been treated for a fractured femoral neck by a Smith-Peterson pin. There was no other explanation for her sacro-iliac fusion and she had no evidence of arthritis. She illustrates the fact that sacro-iliac fusion may occasionally occur without obvious cause. Narrowing did not appear to be related to age in this group.
No difference in erosions or sclerosis was found between patients and controls in this group.

Psoriasis and Arthritis (Table V, overleaf).- In the patients with psoriasis and arthritis there was a significant excess of sacro-iliac joints graded as showing definite narrowing or fusion. Four films showing fusion were withdrawn before consideration of other criteria.

A slight excess of patients was thought to have erosions, but difference is not striking. "Sclerosis" was the same for both patients and controls. We were unable to distinguish the films of those with fused joints from the appearances seen in ankylosing spondylitis.

Ankylosing Spondylitis. - A high proportion of patients with AS was considered to have definite narrowing or fusion of the sacro-iliac joints (Table VI, overleaf). Twenty films with fusion at one or other reading were withdrawn before consideration of other criteria.

TABLE IV

FORTY FILMS FROM PATIENTS WITH SERO-NEGATIVE RHEUMATOID ARTHRITIS AND FORTY CONTROLS

(Key as in Table III)

SUBJECTS

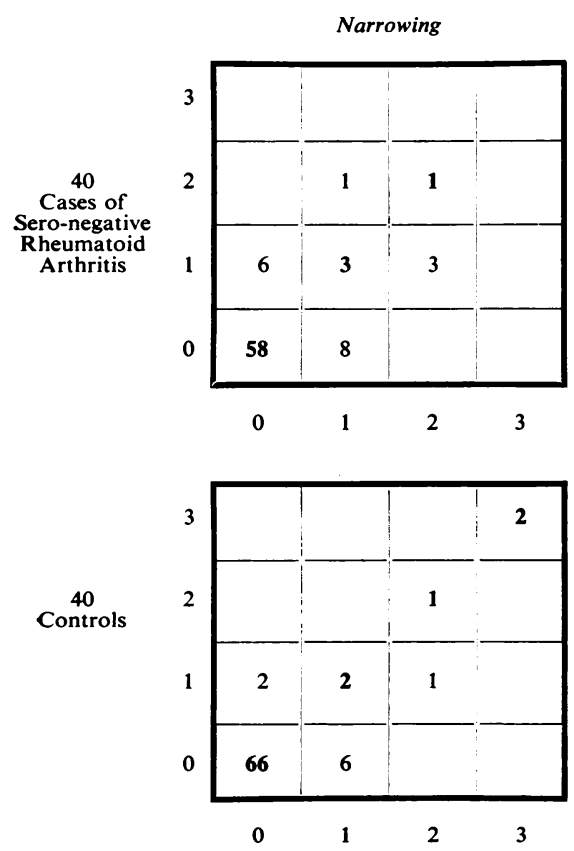

Finms SHOWIng Fusion ARE Excluded
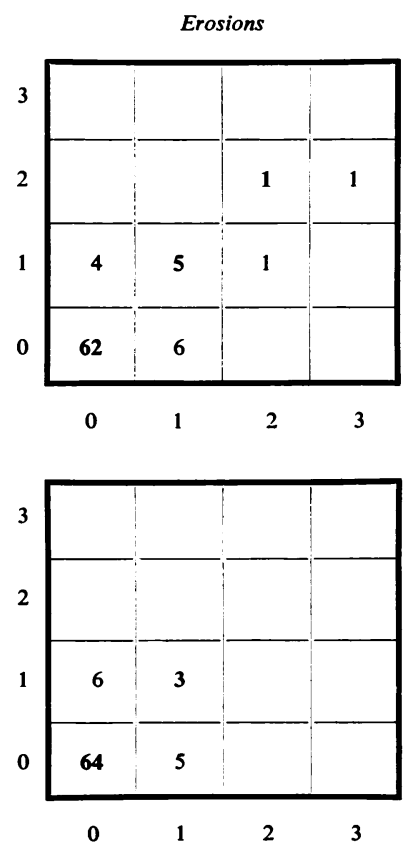

Sclerosis
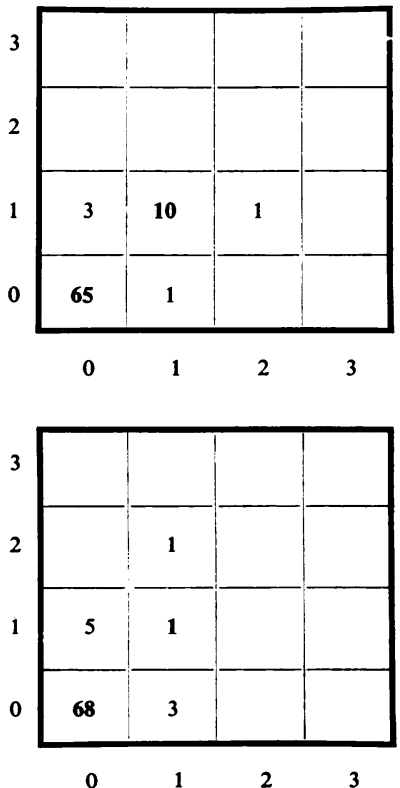


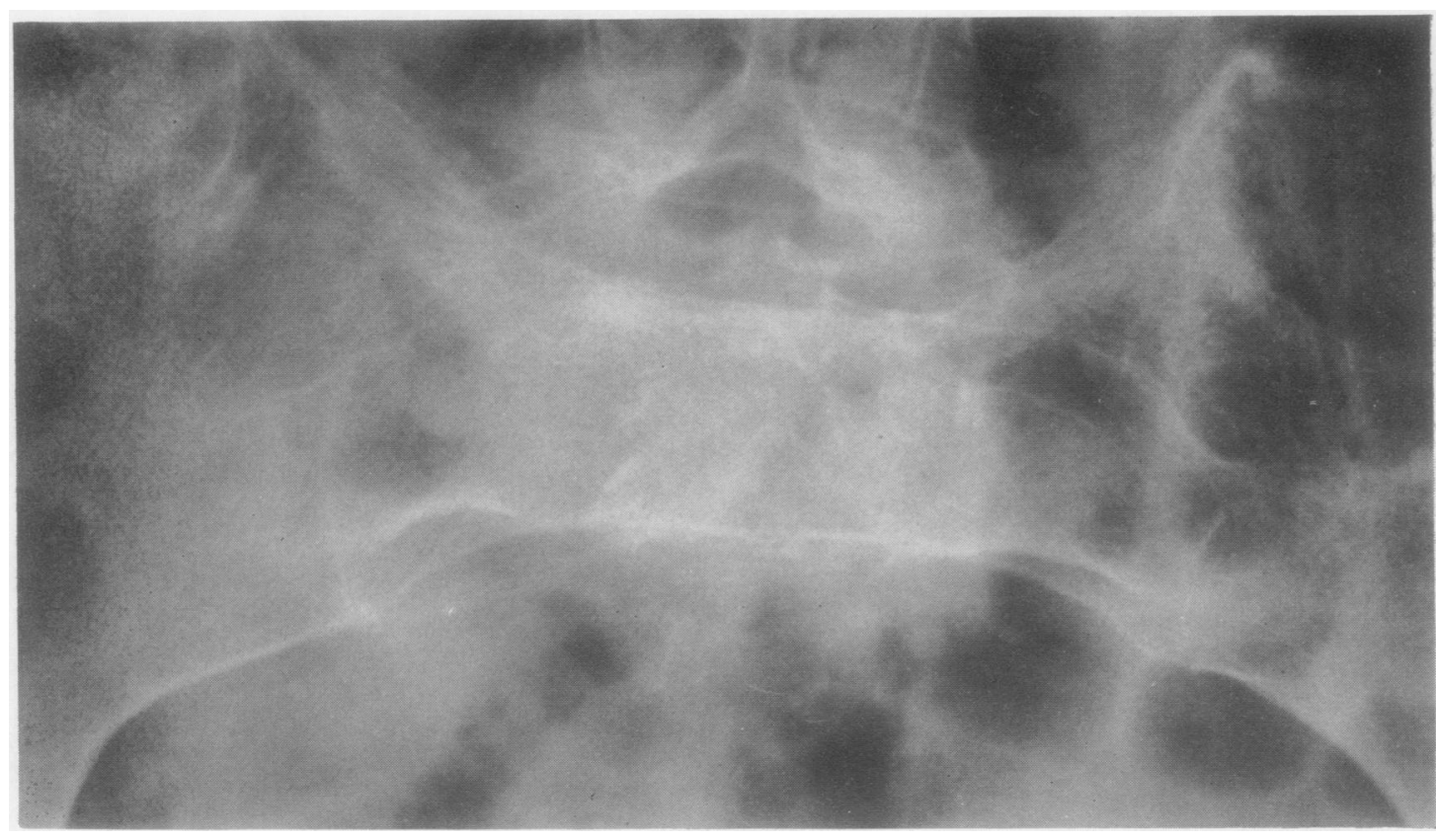

Fig. 4.-Fusion of sacro-iliac joints without ligamentous ossification in a woman aged 74 , a control subject, without arthritis or spondylitis.

TABLE V

33 FILMS FROM PATIENTS WITH PSORIASIS AND ARTHRITIS AND 33 CONTROLS

(Key as in Table III)

SubJeCts

All Films

FILMS SHOWING FUSION ARE EXCLUdED

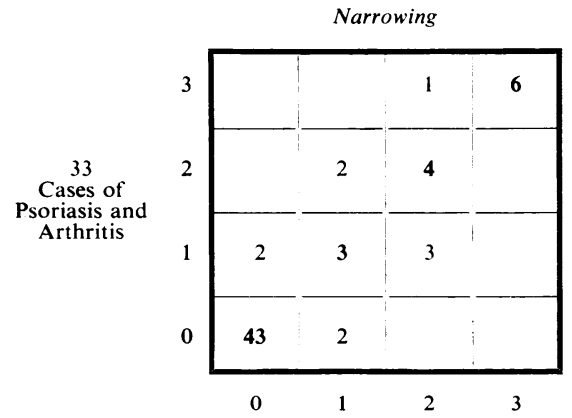

Erosions
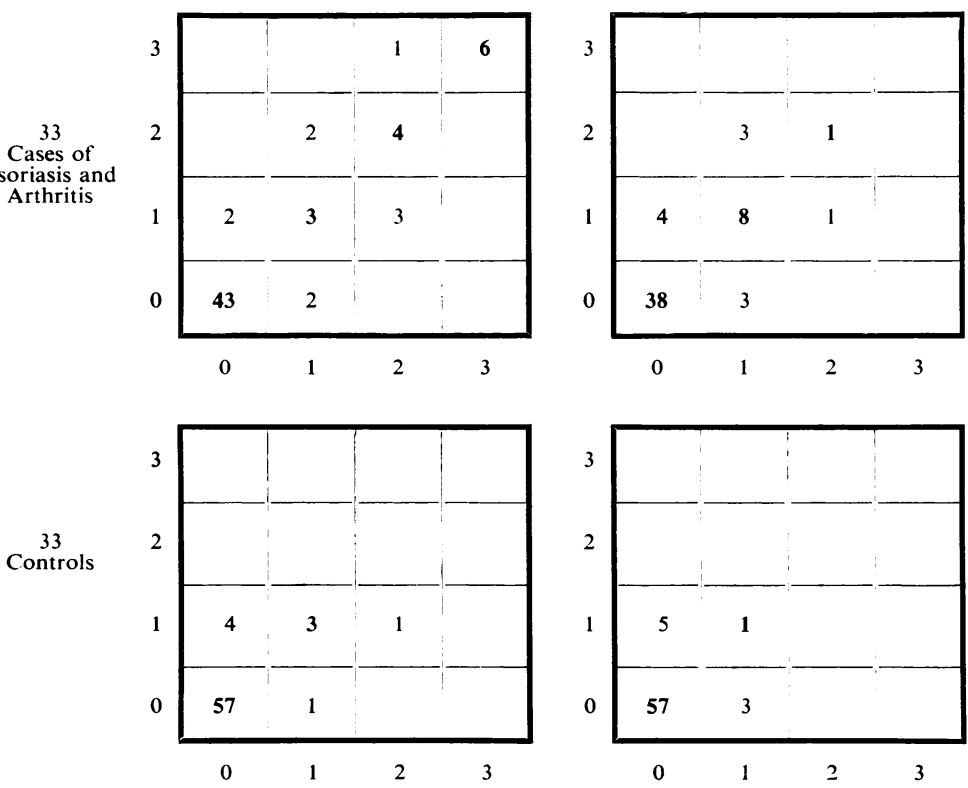

Sclerosi.
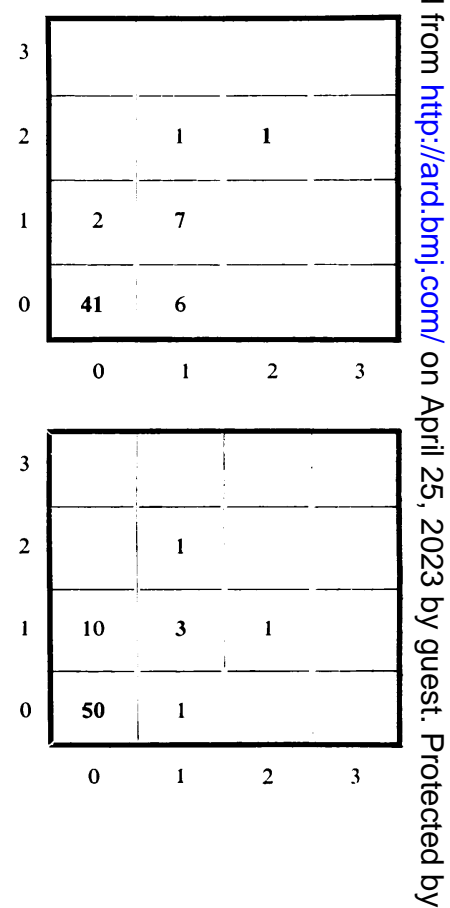
TABLE VI

36 FILMS FROM PATIENTS WITH ANKYLOSING SPONDYLITIS

(Key as in Table III)

SubJECTS

Narrowing

Erosions
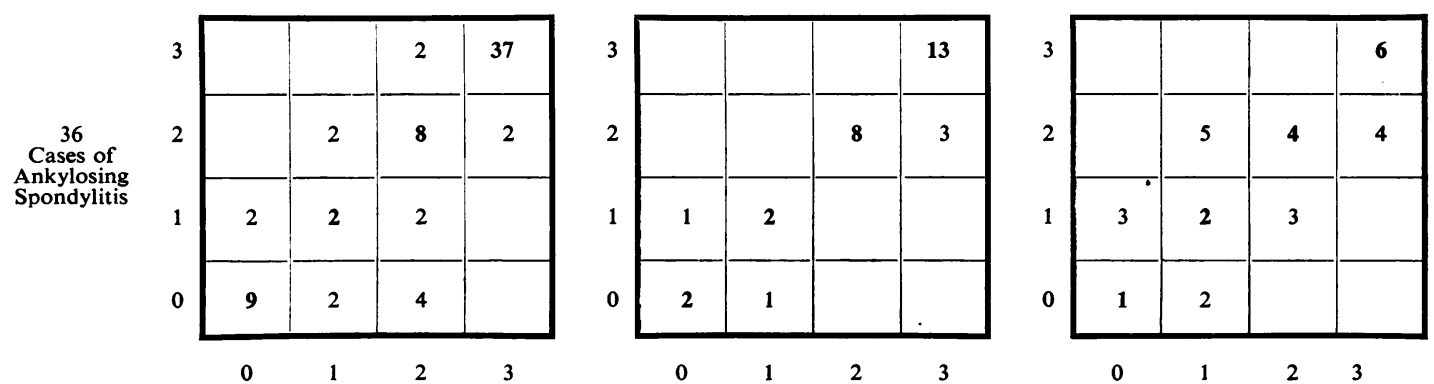

$\begin{array}{llll}0 & 1 & 2 & 3\end{array}$

Of the remainder, only three films were not consistently graded as "definite" (i.e. Grade 2 or more) for erosions or sclerosis. None was consistently thought to be normal (Grade 0 ), but in one case (Fig. 5) only doubtful (Grade 1) changes were recorded at both readings and was thus "missed". This was from a patient with pain down the back of one leg and a normal erythrocyte sedimentation rate, in whom the clinical diagnosis of AS was also doubtful.
Various other signs of AS were seen which did not occur in the other diagnostic group, except in four patients with psoriasis and spondylitis. These included in early cases gross "widening" of the joints (Fig. 6, overleaf), and in late cases "ghost joints", and also "stars"-radiating condensations of trabeculae at the upper end of the sacro-iliac joint (Hart and Robinson, 1959). In addition, the interspinous ligament of the sacrum was often ossified, in late cases producing an appearance rather like the shaft of

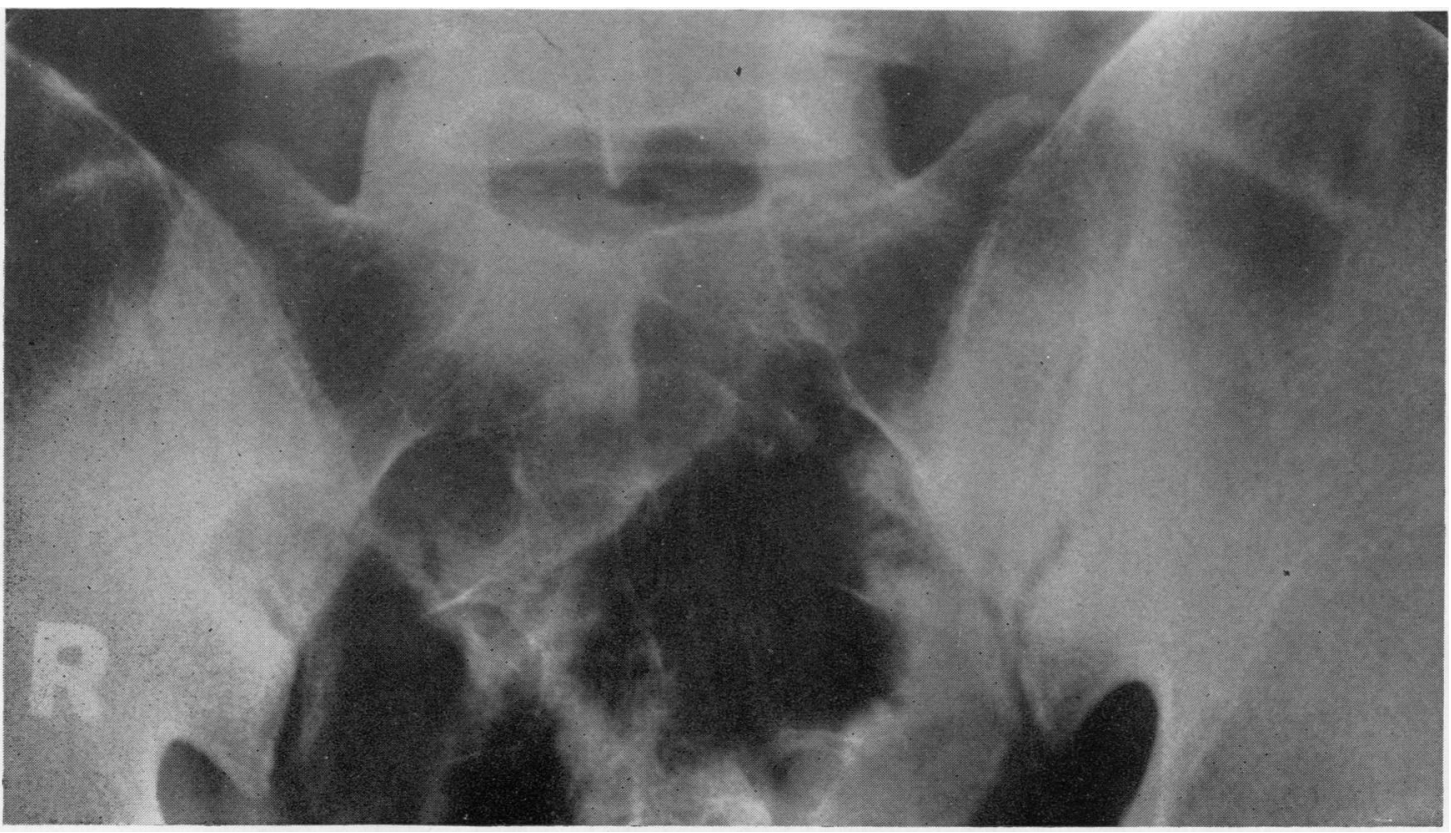

Fig. 5.-Changes in sacro-iliac joints doubtful. Clinical diagnosis of ankylosing spondylitis also doubtful. 


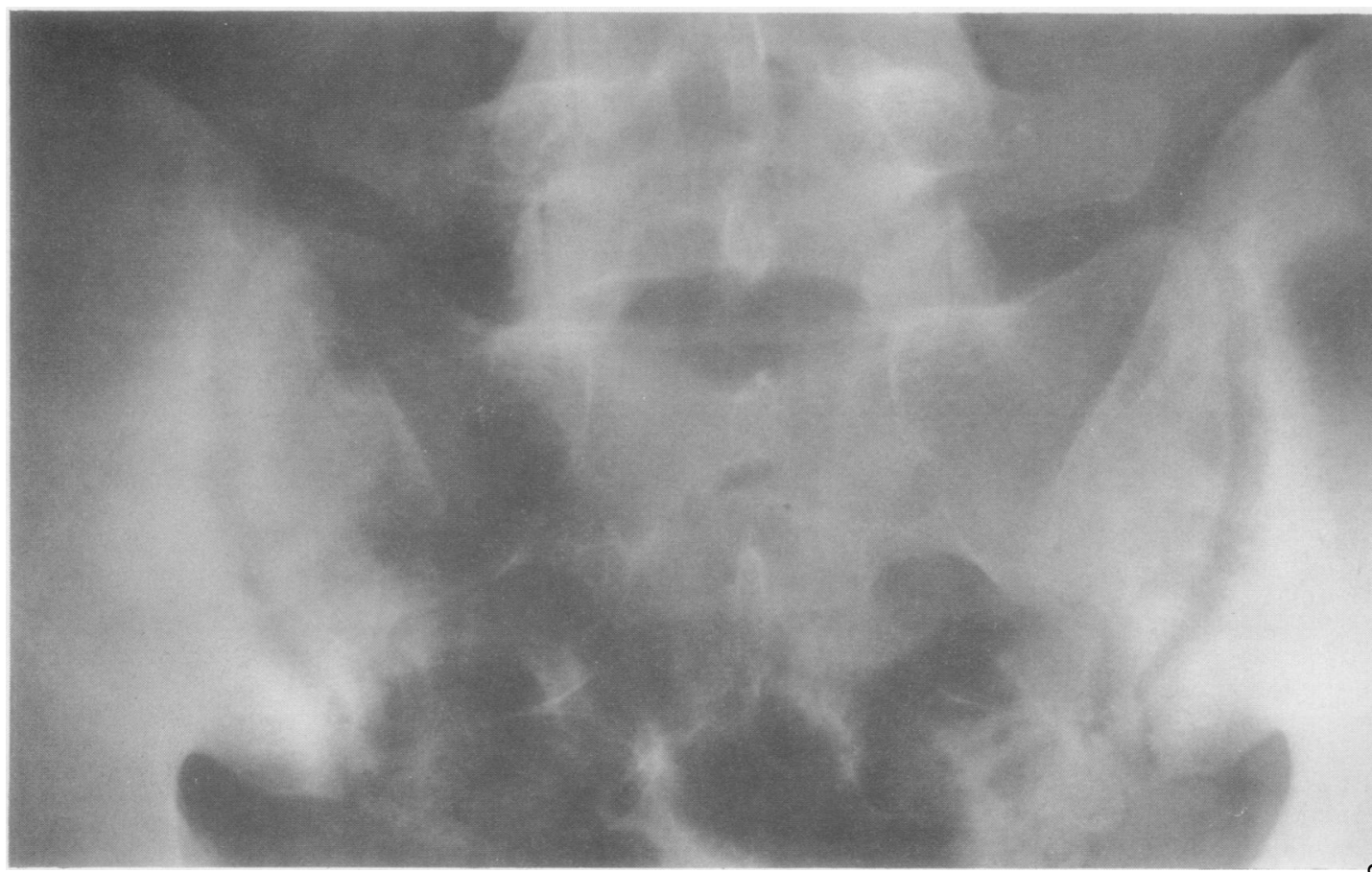

Fig. 6.-A case of ankylosing spondylitis showing gross widening.

a dagger, and the other ligaments, notably the iliolumbar, might also ossify (Fig. 7, opposite). "Stars", the "dagger sign", and gross widening of the joint did not occur in the control and rheumatoid films.

Normal Sacro-iliac Joints. -We also analysed our readings from the point of view of all gradings being normal (i.e. Grade 0 for narrowing, erosions, and sclerosis) and also as probably normal (i.e. Grade 1 or 0 for the same criteria). Results at the second and third reading were similar-those of the third reading are given in Table VII. As mentioned above, the film of one patient with AS was considered probably normal in these respects. For the other diagnostic groups there is a consistent trend for more films from control subjects than from patients to be considered free of definite abnormality, but this is significant only in the comparison of the psoriatic group with their controls.

\section{Discussion}

This study confirms that the sacro-iliac joints may occasionally be affected in rheumatoid arthritis, but that changes when they do occur consist of narrowing of the joint space with or without small, ill-defined erosions and without surrounding sclero-
TABLE VII

NUMBERS OF FILMS THOUGHT NORMAL FOR EROSIONS SCLEROSIS, AND NARROWING

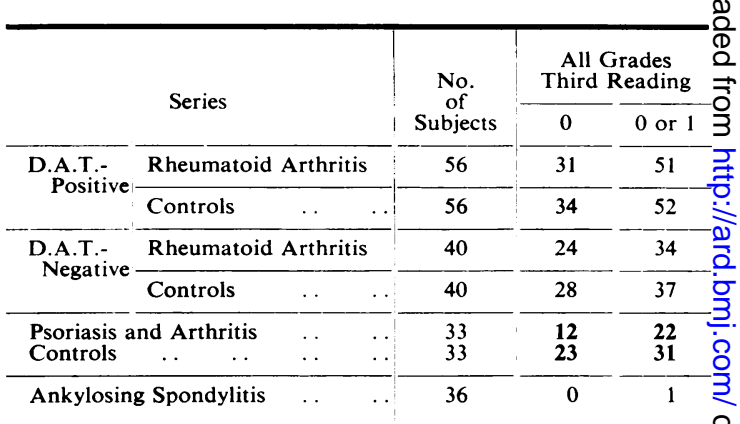

Figures in heavy type indicate significant differences.

sis. In this study these changes were found mainly in older patients with long-standing and severe N disease. In no case did the appearances closely resemble those seen in the sacro-iliac joints in cases N of ankylosing spondylitis.

The controls in this study also included a few? patients with definite changes in the sacro-iliaco joints. They represent the population of "hospitalo attenders", rather than the population as a whole." Through the courtesy of Dr. John Lawrence we 


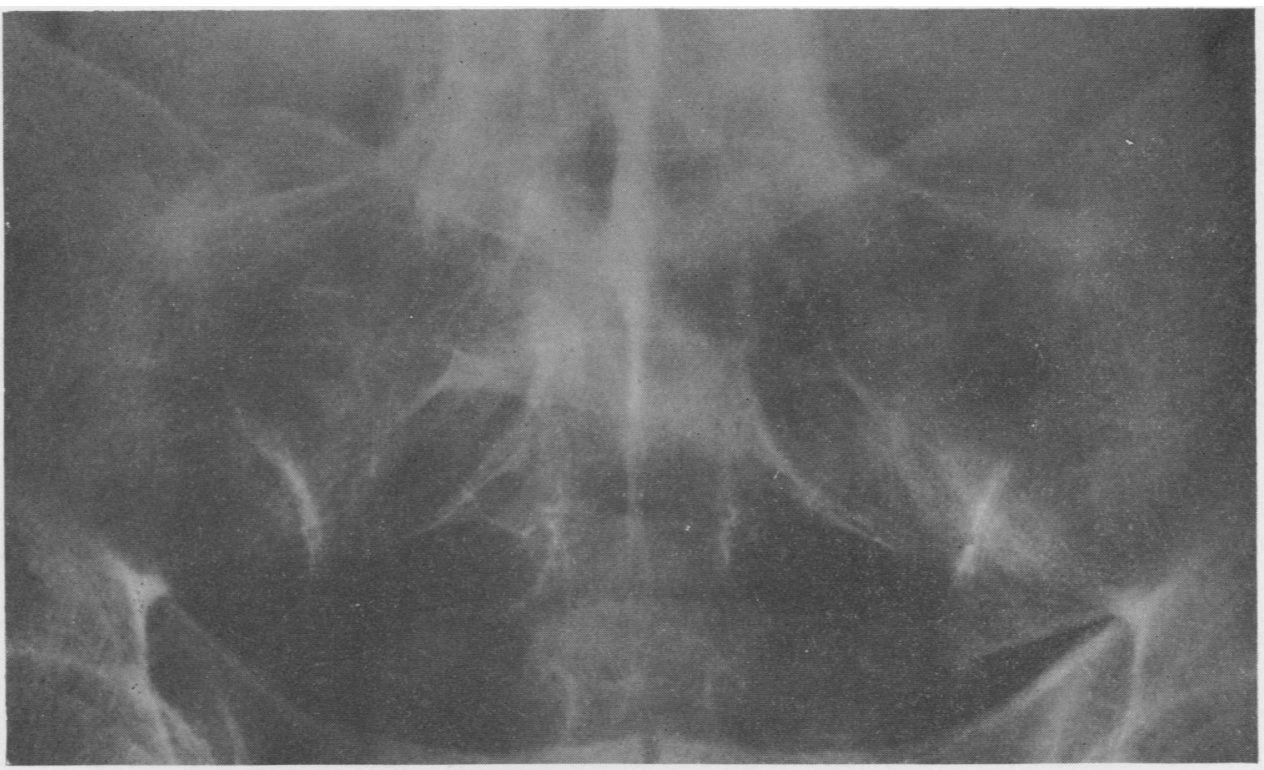

(a)

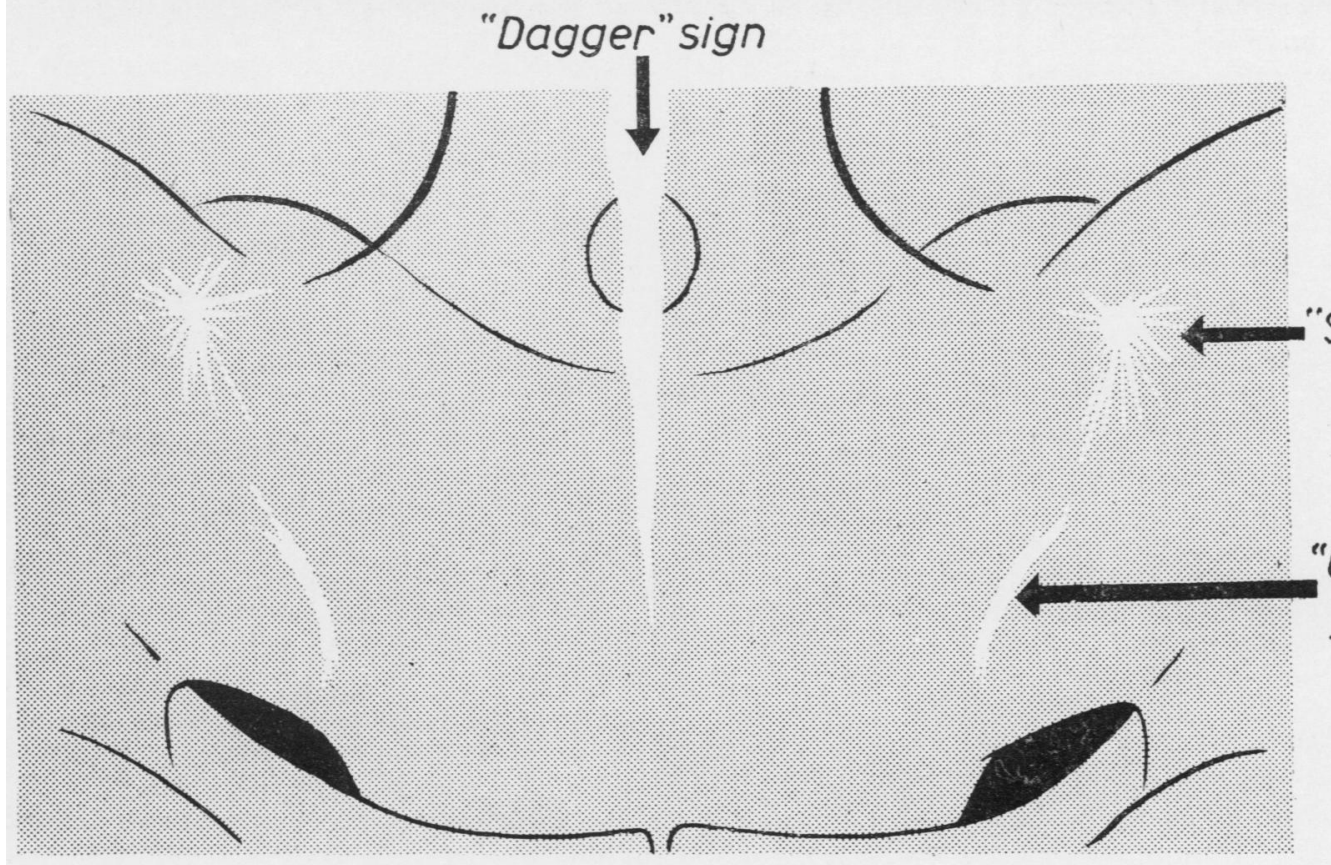

(b)

Fig. 7.-A case of late ankylosing spondylitis, showing the "ghost joints", "stars", and "dagger sign", which were not seen in the rheumatoid arthritis series.

were able to examine pelvic radiographs from a random sample of the normal population in the 55- to 64-year age group; 23 of these were technically comparable and it is of interest that minor degrees of sacro-iliac joint narrowing and the radiological appearance of Grade 1 erosions or sclerosis were occasionally encountered in this small group. 
That the sacro-iliac joint does not escape involvement in generalized sero-positive rheumatoid arthritis is known from autopsy studies (Ball, 1957; Loewi, 1960). We feel, however, that the radiological evidence of this is late in appearance and different from that of ankylosing spondylitis. The validity of radiological examinations of the sacro-iliac joint in differentiating rheumatoid arthritis from ankylosing spondylitis is not impaired.

\section{Summary}

The radiological appearances of the sacro-1liac joints from 56 patients with D.A.T.-positive rheumatoid arthritis, forty with D.A.T.-negative rheumatoid arthritis, and 33 with psoriasis and chronic arthritis were compared with those of a control series comprising a similar number of hospital patients matched for age and sex, and also with those of 36 patients with ankylosing spondylitis. The films were read in random order. Repeatability of reading was satisfactory.

Narrowing of the sacro-iliac joints, without erosions or sclerosis, was found in older patients with long-standing rheumatoid arthritis. The appearances did not resemble those seen in early or late ankylosing spondylitis.

\section{REFERENCES}

Ball, J. (1957). Personal communication.

Cohen, A. S., McNeil, M., Sharp, J. T., Schubart, A., Calabro, J., and Calkins, E. (1959). Summarized in "Second Pan-American Congress on Rheumatic Diseases", p. 41.

Forestier, J., Rotés-Querol, J., and Jacqueline, F. (1950). Rev. Rhum., 17, 407.

Hart, F. Dudley, and Robinson, K. C. (1959). Ann. rheum. Dis., $18,15$.

Lience, E. (1960). M.D. Thesis, University of Barcelona. Loewi, G. (1960). Personal communication.

Ropes, M. W., Bennett, G. A., Cobb, S., Jacox, R., and Jessar, R. A. (1959). Ann. rheum. Dis., 18, 49.

Scott, F. E. T. (1952). Lancet, 1, 392.

Wilkinson, M., and Bywaters, E. G. L. (1958). Ann. rheum. Dis., 17, 209.

\section{DISCUSSION}

DR. V. WRIGHT (Leeds): We have been interested for some time in the clinical and radiological appearances of psoriatic arthritis and for that reason have routinely $x$-rayed the hands, feet, and sacro-iliac joints of all patients with psoriasis and rheumatic complaints. At the last analysis there were 157 patients, of whom 121 had psoriasis with erosive arthritis. Splitting this up, there were 103 with arthritis and a negative DAT, and eighteen with a positive test DAT. There were 99 sacro-iliac joints available for study in the psoriatic patients with negative DAT.

We then took 91 rheumatoid arthritics with a positive DAT and $x$-rayed the sacro-iliac joints. In the patients with psoriatic arthritis and a negative DAT there were erosions in nineteen, ankylosis in eight. In the rheu- $\frac{5}{3}$ matoid group there were erosions in five and ankylosis in one (all unilateral). We took the group of patients with psoriatic arthritis and a positive DAT to have? coincidental rheumatoid arthritis. The incidence of erosive changes in the sacro-iliac joints was the same? as in the rheumatoid group, but in those who werec considered to have psoriatic arthritis it was a good dealo higher. Has Dr. Dixon any information on how his patients' $x$ rays were related to the DAT?

DR. A. G. S. HILl (Stoke Mandeville): We haved available $52 x$ rays of sacro-iliac joints of patients with ${ }^{\text {S }}$ psoriasis and locomotor disease. Nine had a positive $\vec{\circ}$ DAT and none of these had sacro-iliac joint changes;43 had a negative DAT, and ten of these had sclerosis $\vec{\omega}$ or more advanced changes.

DR. J. Forestier (Aix-les-Bains): It is certain that one cannot draw any conclusions from the appearances of bony ankylosis in the sacro-iliac joints. The sameo sort of ankylosis is to be seen on $x$-ray films whateveriw the cause of the ankylosis. Also it is essential to remem-in ber that at the onset of ankylosing spondylitis there is no narrowing in the sacro-iliac joint. There is, as Io described in 1937, a pseudo-enlargement, causing irregular dysfunction and loss of ossification on both sides of the joint line; it is only at a later stage that $\mathbb{D}^{\infty}$ narrowing of the joints is seen in the form of bonyo streaks which appear from place to place.

Psoriatic arthritis is a debatable subject; I do not know? whether there is such a condition as "rheumatoidळ spondylitis" or "psoriatic spondylosis", and it may be that "psoriatic arthritis" is an entity by itself.

DR. Dixon: Dr. Wright and Dr. Hill made substantia聚y. the same point. None of the patients with fusion a d psoriatic arthropathy (or spondylosis) had a positireo DAT, and I am afraid we did not have enough cases with a positive DAT to give you a meaningful break-o down.

I am very glad to have Dr. Forestier's comments. के We referred to the excellent paper by himself, Rotés- $\varrho$ Querol, and Jacqueline on the radiological and ana- $\overrightarrow{0}$ tomical appearance of the sacro-iliac joint in normal3 adults in assessing our own patients.

I am a little worried about this question of a widening of the sacro-iliac joint occurring only in early ankylosing spondylitis, because of the difficulties in dating the onset of ankylosing spondylitis. The condition can only be을 dated from the onset of symptoms. I think that, if we say that all early cases first show widening, we must imagine that the apparently early cases without widening are in fact showing the results of a long era of silent? arthritis.

\section{Articulation sacroiliaque chez l'adulte atteint d'arthrite rhumatismale et d'arthropathie psoriasique \\ RÉSUMÉ}

On compara les images radiologiques des articulations $N$ sacroiliaques de 56 malades atteints d'arthrite rhuma- $N$ tismale et ayant une réaction d'agglutination différen-D tielle positive, de 40 malades avec arthrite rhumatismale et une réaction d'agglutination différentielle négative, eto de 33 malades souffrant de psoriasis et d'arthrite chronique à celles obtenues chez un nombre égal de témoinš hospitalisés, d'âge et sexe comparables, et aussi à des@ radiographies obtenues chez 36 malades atteints de? spondylarthrite ankylosante. La lecture des radio- 7 graphies se fit par hasard, sans aucun ordre. Enō 
répétant les lectures on ne nota pas de divergence d'interprétation statistiquement appréciable.

Chez des malades d'un âge avancé, atteints d'une arthrite rhumatismale de longue durée on trouva un rétrécissement des articulations sacroiliaques, sans érosion ou sclérose. Les images ne ressemblèrent pas à celles observées dans la spondylarthrite ankylosante au début ou avancée.

\section{La articulación sacroiliaca en adultos con artritis reumatoide y artropatia psoriásica SUMARIO}

Se compararon las imágenes radiológicas de las articulaciones sacroiliacas halladas en 56 enfermos con reacción de aglutinación diferencial positiva y artritis reumatoide, en 40 con esta reacción negativa y artritis reumatoide y en 33 con psoriasis y artritis crónica, con aquellas obtenidas en series de control comprendiendo un número similar de enfermos hospitalarios de edad y sexo comparables, y también con radiografías obtenidas en 36 enfermos con espondilartritis anquilosante. La lectura de las radiografías se realizó al azar, sin previo orden. Repetición de las lecturas no reveló divergencia estadísticamente apreciable.

En enfermos de edad avanzada, sufriendo de artritis reumatoide por largo tiempo se encontró estrechamiento de las articulaciones sacroiliacas, sin erosiones o esclerosis. Las imágenes no eran similares a las observadas en espondilartritis anquilosante incipiente o avanzada. 